\title{
FUNGSI LEMBAGA PENJAMIN SIMPANAN DALAM HUKUM PERBANKAN INDONESIA
}

\author{
Hendri Jayadi \& Prof. Dr. Huala Adolf, S.H, LL.M \\ Kandidat Doktor Fakultas Hukum Universitas Padjajaran \\ Email: Jayadihendrilaw@gmail.com
}

\begin{abstract}
ABSTRAK
Dalam praktek hukum perbankan, suatu bank dapat dicabut ijin usahanya dan mengalami likuidasi. Didalam proses likuidasi bank Lembaga Penjamin Simpanan berperan penting dalam menyelesaikan pengembalian dana simpanan para nasabah bank tersebut ketika bank mengalami likuidasi terkait pembayaran klaim penjaminan simpanan nasabah bank yang dicabut izinnya, Lembaga Penjamin Simpanan memiliki hak untuk menggantikan posisi nasabah penyimpan tersebut (hak subrogasi) dalam pembagian hasil likuidasi bank. Pemberian kewenangan dan hak tersebut dimaksudkan untuk mengoptimalkan tingkat pemulihan (recovery rate) bagi Lembaga Penjamin Simpanan, agar keberlangsungan program penjaminan simpanan dapat terus dijaga. Lahirnya Undang-undang Nomor 24 Tahun 2004 tentang Lembaga Penjamin Simpanan menandai babak baru sistem perbankan nasional. Keberadaan Lembaga Penjamin Simpanan ini tidak bisa dilepaskan dari upaya peningkatan stabilitas sektor keuangan dan untuk memulihkan kepercayaan masyarakat terhadap sektor perbankan. Penelitian ini difokuskan pada peran dan fungsi Lembaga Penjamin Simpanan dalam melaksanakan tugas dan tanggung jawabnya untuk menjamin, melindungi dan memberikan kepastian hukum kepada masyarakat sebagai nasabah bank dalam likuidasi bank dalam hukum perbankan.
\end{abstract}

Kata Kunci: Fungsi, Lembaga Penjamin Simpanan, Perbankan.

\begin{abstract}
In the practice of banking law, a bank may be revoked of its business license and liquidated. In the liquidation process of the Deposit Insurance Institution bank plays an important role in settling the deposit of the bank's customers when the bank is liquidated in relation to the payment of the deposit guarantee claim of the bank customer whose license is revoked, the Deposit Insurance Agency has the right to replace the depositor's position (subrogation rights) in the division result of bank liquidation. The grant of authority and rights is intended to optimize the recovery rate for the Deposit Insurance Corporation, so that the sustainability of the deposit guarantee program can be maintained. The emersion of Law Number 24 Year 2004 on Deposit Insurance Corporation marked a new chapter of the national banking system. The existence of the Deposit Insurance Agency can not be separated from efforts to improve financial sector stability and to restore public confidence in the banking sector. This study focuses on the role and function of the Deposit Insurance Agency in performing its duties and responsibilities to ensure, protect and provide legal certainty to the public as bank customers in bank liquidation in banking law.
\end{abstract}

Keywords: Functions, Deposit Insurance Corporation, Banking. 


\section{Pendahuluan}

Perkembangan sistem perbankan Indonesia telah berevolusi dalam lima tahap, yakni (1) tahap rehabilitasi dan perbaikan dari inflasi tinggi tahun 19671973, (2) tahap pemberlakuan pagu aktiva neto tahun 1974-1983, (3) tahap pertumbuhan dan (4) tahap deregulasi tahun 1983-1988, tahap percepatan tahun 1988-1991, serta (5) tahap konsolidasi tahun 1991-1997, yakni masa prinsip-prinsip kehati-hatian yang sedang diperkenalkan termasuk kecukupan modal dan peringkat Bank (S. Batunanggar;2002). Krisis telah terlanjur merebak menjadi krisis dalam skala makro dimensial baik secara politik, sosial dan ekonomi. Hal ini terjadi semasa tahap konsolidasi sedang berjalan, sementara kondisi fundamental bank-bank masih lemah, antara lain kecukupan modal yang belum teratasi. Restrukturisasi yang cukup signifikan nyatanya tidak cukup membantu, sektor perbankan Indonesia tetap lemah dan hal tersebut setidaktidaknya disebabkan oleh tiga hal (Mari Elka Pangestu;2003) :

1. Pertumbuhan jumlah bank yang amat pesat sebagai hasil kebijakan deregulasi 1988 yang tidak disertai dengan ketentuan prudensial dan pengawasan yang memadai oleh bank sentral;

2. Lemahnya penerapan good corporate governance di sektor perbankan karena konsentrasi kepemilikan amat tinggi;

3. Terjadinya economic boom uan integrasi keuangan internasional yang mengakumulasi tingkat kerentanan sistem perbankan Indonesia.

Industri perbankan merupakan salah satu komponen sangat penting dalam perekonomian nasional demi menjaga keseimbangan, kemajuan dan kesatuan ekononomi nasional. Hal ini dikarenakan kegiatan perekonomian suatu negara tidak pernah terlepas dari lalu lintas pembayaran uang, di mana industri perbankan memegang peranan yang sangat strategis sehingga dapat dikatakan sebagai pusat dari sistem perekonomian.

Peran stategis yang dimiliki perbankan dalam perekonomian nasional telah mendorong lahirnya berbagai kebijakan, tetapi tidak semua kebijakan dan aturan yang pernah diterapkan terhdap dunia perbankan nasional membawa dampak yang positif. Pada tahun 1988 pemerintah mengeluarkan Paket Deregulasi Oktober 1988 (Pakto 1988). Paket deregulasi ini sangat memberikan kemudahan bagi pertumbuhan bank- bank swasta. Materi yang diatur oleh Pakto 1988 adalah (Munir Fuady, 2003):

1. Pendirian bank umum dan bank pembangunan swasta dibebaskan dengan syarat mempunyai modal setor hanya sebesar Rp. 50.000.000.000,00 (lima puluh milyar rupiah).

2. Seluruh bank nasional dapat membuka kantor cabangnya di seluruh wilayah Indonesia asalkan memenuhi persyaratan 24 (dua puluh empat) bulan terakhir tergolong sehat.

3. Perluasan kesempatan mendirikan Bank Perkreditan Rakyat dan memperluas kewenangannya.

4. Mempermudah pengakuan atau pemberian status kepada bank devisa.

5. Mempermudah bank asing untuk membuka cabang-cabangnya di 5 (lima) kota besar yaitu Jakarta, Bandung, Semarang, Surabaya, Medan dan Ujung Pandang. 
6. Mempermudah pendirian bankbank campuran (patungan) di 5 (lima) kota besar tersebut.

Keterkaitan dan kepercayaan masyarakat kepada industri perbankan merupakan pilar dan unsur utama yang harus dijaga dan dipelihara. Kepercayaan ini dapat diperoleh dengan adanya kepastian hukum dalam pengaturan dan pengawasan bank serta penjaminan simpanan nasabah bank untuk meningkatkan kelangsungan usaha bank secara sehat. Dengan demikian maka bagi pemerintah dan kalangan perbankan perlu sekali untuk tetap selalu membangkitkan pemahaman yang benar dari masyarakat terhadap industri perbankan. Hal itu telah diatur dan merupakan satu kewajiban yang tercantum dalam Undang-Undang Perbankan.

Kegiatan pokok bank yang menghimpun dana dari masyarakat dan menyalurkannya kembali kepada masyarakat dengan tujuan menunjang pelaksanaan pembangunan nasional dalam rangka meningkatkan pemerataan pertumbuhan ekonomi serta stabilitas nasional ke arah peningkatan kesejahteraan rakyat Indonesia secara menyeluruh. Jika industri perbankan dalam kondisi yang stabil dan baik, tentunya ini akan memberikan pengaruh positif terhadap perekonomian suatu negara, namun jika yang terjadi adalah sebaliknya maka akan memberikan pengaruh negatif terhadap perekonomian suatu negara bahkan meluas kepada sektor lainnya.

Pada awal tahun 2009 dunia perbankan Indonesia kembali dikejutkan dengan adanya keputusan Bank Indonesia yang sangat kontroversial terhadap dua bank yakni Bank Century dan Bank IFI. Kebijakan yang diambil oleh pemerintah terhadap
Bank Century adalah bill out, sedangkan terhadap Bank IFI adalah likuidasi.

Pada tanggal 17 April 2009 Bank Indonesia mengambil keputusan untuk melikuidasi Bank IFI yang merupakan salah satu bank swasta yang berkantor pusat di Jakarta. Keputusan Bank Indonesia mengenai likuidasi tersebut bukan merupakan suatu keputusan yang tidak mendasar, akan tetapi pasti hal ini didasari oleh suatu pertimbangan matang yang dipandang dari segi yuridis maupun bisnis. Pada hakikatnya, langkah-langkah yang dapat disebut sebagai program penyelesaian krisis perbankan di Indonesia dapat dikelompokan ke dalam tiga bagian besar, yaitu (Kusumaningtuti;2010) :

1. Kelompok penanggulangan yang terdiri dari :

a. Exit policy;

b. Bantuan Likuiditas Bank Indonesia (BLBI);

c. Blanket guarantee atau penjaminan pemerintah.

2. Kelompok penyehatan yang terdiri dari :

a. Pendirian Badan

Penyehatan Perbankan

Nasionla (BPPN);

b. Penyelesaian asset;

c. Akuisisi, merger, dan konsilidasi;

d. Rekapitalisasi bank-bank.

3. Kelompok penguatan ketahanan yang terdiri dari :

a. Restruktirisasi kredit;

b. Jaring pengaman keuangan (financial safety net).

Definisi atau batasan mengenai Bank pada dasarnya tidak berbeda satu sama lain, kalaupun ada perbedaan hanya pada tugas dan jenis usaha bank tersebut. Menurut G.M. Verryn Stuart, "Bank Politik", adalah sebagai berikut (Thamrin Abdullah;2008) : Bank adalah suatu badan yang bertujuan untuk 
memuaskan kebutuhan kredit, baik dengan alat-alat pembayarannya sendiri atau dengan uang yang diperolehnya dari orang lain, manapun dengan jalan memperedarkan alat-alat penukar dan tempat uang giral.

Secara yuridis berdasarkan Undang-Undang Nomor 7 Tahun 1992 jo Undang-Undang Nomor 10 Tahun 1998 tentang Perbankan (selanjutnya akan disebut UU Perbankan) yang dimaksud dengan bank adalah badan usaha yang menghimpun dana masyarakat dalam bentuk simpanan dan menyalurkannya kepada masyarakat dalam rangka meningkatkan taraf hidup rakyat banyak. Berdasarkan definisi tersebut maka produk yang ditawarkan oleh bank kepada konsumen adalah menerima simpanan dari konsumen atau nasabah dan menyalurkannya kepada masyarakat dalam bentuk pinjaman atau kredit. Hal ini merupakan fungsi ekonomis dari bank yang dalam prakteknya menjadi lembaga yang menerima simpanan, menawarkan rekening dengan hak istimewa dan membuat pinjaman, sebagai bagian yang tidak terpisahkan dari perannya sebagai financial intermediary atas jasa transaksi kepada konsumen. Pendekatan fungsi ekonomis yang dianggap paling memuaskan sebagai financial intermediary bank akan mengambil uang dari nasabah, mengumpulkan, menanamkan kembali dana tersebut pada perusahaan lain dalam bentuk kredit, saham, go public ke pasar modal dan lain-lain. Berdasarkan hal tersebut maka disimpulkan bank adalah institusi yang berada diantara investor (nasabah awal) dengan investor (nasabah paling akhir/peminjam).

Dalam menjalankan usahanya bank memiliki sifat khusus dibanding dengan badan usaha jasa keuangan lainnya. Adapun sifat khususnya adalah :
1. Sebagai salah satu sub-sistem industri jasa keuangan. Bank disebut sebagai jantung atau motor penggerak roda perekonomian suatu negara, salah satu leading indicator kestabilan tingkat perekonomian suatu negara. Indikator perekonomian negara sedang sakit, salah satunya jika perbankan mengalami keterpurukan.

2. Industri perbankan adalah industri yang sangat bertumpu kepada kepercayaan masyarakat (fiduciary financial institution). Kepercayaan masyarakat adalah segala-galanya bagi bank. Begitu masyarakat tidak percaya pada bank, bank akan menghadapi rush yaitu penarikan simpanan oleh para nasabahnya secara bersamaan dan besarbesaran dan pada akhirnya bank mengalami kondisi colaps. Amerika Serikat pada abad 19-20, setiap 20 tahun sekali terjadi krisis perbankan sebagai akibat krisis kepercayaan.

Berdasarkan dua sifat khusus tersebut, industri perbankan adalah industri yang sangat banyak diatur oleh pemerintah (most heavily regulated industries). Revisi serta penegakannya harus dilakukan sangat hati-hati dengan memperhatikan akibat ekonomi dan fungsi perbankan dalam perekonomian negara serta kepercayaan masyarakat yang harus dijaga.

Penelitian ini difokuskan pada peranan pemerintah dalam penyelesaian bank bermasalah yang mengalami likuidasi dan proses penyelesaiannya.Berdasarkan ketentuan Pasal 37 ayat (3) dan (4) UU Perbankan disebutkan bahwa suatu bank dapat dicabut ijin usahanya oleh menteri dalam hal ini adalah Menteri Keuangan Republik Indonesia berdasarkan usulan 
dari Bank Indonesia, kemudian memerintahkan agar proses likuidasi terhadap bank tersebut segera dilaksanakan. Pengertian likuidasi bank berdasarkan ketentuan Pasal 17 ayat (1) Peraturan Pemerintah No. 68 Tahun 1996 tentang Ketentuan dan Tata Cara Pencabutan Izin Usaha, Pembubaran dan Likuidasi Bank, yaitu tindakan pemberesan berupa penyelesaian seluruh hak dan kewajiban bank sebagai akibat pembubaran badan hukum bank.

Dalam praktek hukum perbankan, suatu bank dapat dicabut ijin usahanya dan mengalami likuidasi apabila memenuhi syarat-syarat sebagaimana diatur dalam penjelasan Pasal 2 ayat (1) Peraturan Pemerintah No. 68 Tahun 1996 tentang Ketentuan dan Tata Cara Pencabutan Izin Usaha, Pembubaran dan Likuidasi Bank. Bank dalam likuidasi adalah suatu bank dalam keadaan mengalami kesulitan yang membahayakan kelangsungan usahanya apabila berdasarkan penelitian Bank Indonesia, bank berada dalam kondisi usaha yang semakin memburuk hal mana ditandai dengan :

1. Menurunnya permodalan;

2. Menurunnya kualitas asset;

3. Menurunnya rentabilitas;

4. Menurunnya likuiditas;

5. Pengelolaan bank tidak dilakukan berdasarkan prinsip kehati-hatian dan azas perbankan yang sehat.

Bank-bank yang telah memenuhi syarat-syarat tersebut, secara langsung akan berada dalam pengawasan Bank Indonesia. Bahkan dalam prakteknya Bank Indonesia memiliki kewenangan untuk memanggil Para Pengurus, Komisaris dan Pemegang Saham pada bank tersebut untuk memberikan kesempatan-kesempatan guna memperbaiki keadaan perbankan pada bank-nya tersebut. Kesempatan yang diberikan oleh Bank Indonesia adalah
Para Pengurus dan Pemegang Saham pada bank tersebut wajib untuk menambah dana atau modal guna meningkatkan modal pada bank tersebut. Kesempatan yang diberikan oleh Bank Indonesia memiliki batasan waktu, sehingga apabila dalam batas tenggang waktu yang ditentukan Para Pengurus dan Pemegang Saham pada bank tersebut tidak juga secara nyata menyelesaikan permasalahan pada bank tersebut dengan cara menambah dana atau modal guna meningkatkan permodalan maka Bank Indonesia akan mengusulkan kepada menteri agar mengeluarkan keputusan untuk mencabut ijin usaha dari bank tersebut dan kemudian melakukan likuidasi terhadap bank tersebut.

Saat ini mengenai ketentuan dan tata cara pencabutan izin usaha, pembubaran dan likuidasi bank, diatur dalam Peraturan Pemerintah No. 25 Tahun 1999 tentang Ketentuan dan Tata Cara Pencabutan Izin Usaha, Pembubaran dan Likuidasi Bank. Berdasarkan ketentuan tersebut Bank Indonesia memiliki kewenangan penuh untuk mencabut ijin usaha perbankan, bahkan untuk membentuk team likuidasi tanpa harus membuat usulan kepada Menteri Keuangan. Hal tersebut diatur dalam ketentuan Pasal 4 ayat (1) Peraturan Pemerintah No. 25 Tahun 1999 yang mengatur tentang Pencabutan izin usaha bank dilakukan oleh Pimpinan Bank Indonesia.

Proses penutupan suatu bank belum diketahui apakah ketika Bank Indonesia memutuskan untuk mencabut ijin usaha bank kemudian melikuidasi suatu bank, Bank Indonesia telah menyiapkan langkah-langkah strategis untuk menyelesaikan permasalahan yang muncul, khususnya mengenai pengembalian simpanan dana para nasabah bank pada bank dalam likuidasi 
tersebut. Persoalan lain akan muncul kembali terkait aset-aset yang dimiliki oleh Bank dalam likuidasi tersebut jumlahnya atau nilainya lebih kecil daripada simpanan dana para nasabah bank tersebut. Permasalahan lain akan muncul terkait kredit-kredit yang pernah diberikan oleh bank dalam likuidasi tersebut kepada nasabah yang memiliki kredit pada bank dalam likuidasi tersebut, pihak mana dan berkenaan dengan cara pengelolaannya. Jika hal ini telah diantisipasi oleh Bank Indonesia pasti proses likuidasi serta pengembalian simpanan dana nasabah akan terjamin dan berjalan dengan baik. Masalah ini yang kerap kali muncul dalam hal terjadinya likuidasai terhadap bank sampai dengan saat ini.

$\begin{array}{crr}\text { Ketentuan } & \text { hukum mengenai } \\ \text { pengawasan } & \text { terhadap lembaga }\end{array}$
keuangan khususnya bank ditambah dengan adanya Undang-Undang Nomor 21 Tahun 2011 tentang Otoritas Jasa Keuangan (selanjutnya disebut UUOJK), terhitung sejak 31 Desember 2013, ditandai dengan ditandatanganinya berita acara serah terima antara Bank Indonesia dan Otoritas Jasa Keuangan.

Otoritas Jasa Keuangan selain sebagai pengawas lembaga keuangan termasuk didalamnya adalah perbankan. Indonesia juga memiliki lembaga yang berbentuk badan hukum independen yang diberi nama Lembaga Penjamin Simpanan yang didirikan berdasarkan Undang-Undang No. 24 Tahun 2004 tentang Lembaga Penjamin Simpanan (selanjutnya disebut UU Lembaga Penjamin Simpanan). Lembaga Penjamin Simpanan adalah merupakan penyempurnaan program penjaminan pemerintah terhadap seluruh kewajiban bank (blanket guarantee).

Fungsi Lembaga Penjamin Simpanan adalah menjamin simpanan nasabah penyimpan dan turut aktif dalam memelihara stabilitas sistem perbankan sesuai dengan kewenangannya. Fungsi penjaminan diejawantahkan dengan melakukan pembayaran klaim penjaminan atas simpanan nasabah bank yang dicabut izinnya dan menunjuk tim likuidasi untuk membereskan aset dan kewajiban bank tersebut, sedangkan fungsi turut aktif memelihara stabilitas sistem perbankan diwujudkan dalam bentuk upaya menyelamatkan atau penyehatan terhadap bank gagal yang tidak berdampak sistemik maupun bank gagal yang terdampak sistemik (bank resolution).

Keputusan menyelamatkan atau tidak menyelamatkan bank gagal tidak berdampak sistemik ditetapkan oleh Lembaga Penjamin Simpanan. Salah satu pertimbangannya didasarkan pada penghitungan biaya yang lebih rendah (lower cost test) antara menyelamatkan bank tersebut dengan membayar klaim penjaminan. Keputusan untuk menyelamatkan gagal yang berdampak sistemik ditetapkan dan diserahkan oleh Komite Koordinasi (KK) yang terdiri dari Menteri Keuangan, Gubernur Bank Indonesia (BI), dan Ketua Dewan Komisioner. Setelah itu, Lembaga Penjamin Simpanan bertindak sebagai pelaksana dalam penyelamatan bank gagal yang telah diputuskan berdampak sistemik. Dalam upaya dalam menyelamatkan bank gagal, Lembaga Penjamin Simpanan mempunyai kewenangan, antara lain mengambil alih dan menjalankan segala hak dan wewenang pemegang saham, termasuk RUPS; menguasai, mengelola, dan menjual / mengalihkan aset bank; melakukan penyertaan modal sementara (PMS); serta mengalihkan manajemen pada pihak lain. Lembaga Penjamin Simpanan mempunyai jangka waktu penyelamatan paling lama empat 
tahun untuk bank tidak berdampak sistemik dan lima tahun untuk bank gagal yang berdampak sistemik. Selanjutnya, Lembaga Penjamin Simpanan harus menjual seluruh saham bank yang diperoleh dari penyertaan modal sementara (PMS) secara terbuka dan transparan.

Mengenai pembayaran klaim penjaminan simpanan nasabah bank yang dicabut izinnya, Lembaga Penjamin Simpanan memiliki hak untuk menggantikan posisi nasabah penyimpan tersebut (hak subrogasi) dalam pembagian hasil likuidasi bank. Pemberian kewenangan dan hak tersebut dimaksudkan untuk mengoptimalkan tingkat pemulihan (recovery rate) bagi Lembaga Penjamin Simpanan, agar keberlangsungan program penjaminan simpanan dapat terus dijaga.

Lembaga perbankan merupakan inti dari sistem keuangan dari setiap negara. Bank adalah lembaga keuangan yang menjadi tempat bagi perseorangan, badan badan usaha swasta, badan badan usaha milik negara, bahkan lembaga lembaga pemerintahan menyimpan dana dana yang dimilikinya. Melalui kegiatan perkreditan dan berbagai jasa yang diberikan, bank melayani kebutuhan pembiayaan serta melancarkan mekanisme sistem pembayaran bagi semua sektor perekonomian (Hermansyah;2010).

Pada dasarnya usaha bank dilandasi oleh hubungan kepercayaan antara bank dengan masyarakat nasabah bank. Bank terutama bekerja dengan dana dari masyarakat yang disimpan pada bank atas dasar kepercayaan, sehingga setiap bank perlu terus menjaga kesehatannya dengan tetap memelihara dan sekaligus mempertahankan kepercayaan masyarakat.

Kemauan masyarakat untuk menyimpan sebagian atau seluruh uangnya di bank, semata-mata dilandasi oleh prinsip kepercayaan bahwa uangnya akan aman dan tetap akan dapat diperolehnya kembali pada waktu yang diinginkan atau sesuai dengan yang diperjanjikan, dan disertai pemberian imbalan. Apabila kepercayaan nasabah penyimpan dana terhadap suatu bank telah berkurang, maka tidak tertutup kemungkinan akan terjadi rush terhadap dana yang disimpannya. Bagi para pelaku sektor keuangan, keadaan tahun 1997 dan 1998 adalah lembaran hitam dalamsejarah industri keuangan. Situasi tak terkendali pada saat itu jelas tidak bisa dibiarkan begitu saja.Untuk itu, tahun 1998, pemerintah mengeluarkan kebijakan untuk memberikan jaminan atas seluruh kewajiban pembayaran bank umum (blanket guarantee).Badan Penyehatan Perbankan Nasional

(BPPN) kemudian dibentuk pemerintah guna melakukan penyehatan perbankan, penyelesaian aset bermasalah, dan mengupayakan pengembalian uang negara yang tersalur pada sektor perbankan. Dengan kebijakan blanket guarantee ini, pemerintah menjamin pembayaran terhadap seluruh kewajiban bank termasuk pembayaran simpanan masyarakat di bank jika suatu bank dilikuidasi.

$$
\text { Lahirnya Undang-undang }
$$

Nomor 24 Tahun 2004 tentang Lembaga Penjamin Simpanan menandai babak baru sistem perbankan nasional.Keberadaan Lembaga Penjamin Simpanan ini tidak bisa dilepaskan dari upaya peningkatan stabilitas sektor keuangan dan untuk memulihkan kepercayaan 
masyarakat terhadap sektor perbankan.Masyarakat diharapkan tak lagi khawatir menyimpan uangnya di bank. Karena apabila terjadi krisis pada suatu bank, uang masyarakat akan tetap aman dan mendapat jaminan pengembalian dari pemerintah. Dengan kebijakan ini pemerintah juga berharap kondisi sektor keuangan tetap stabil. Sekaligus pada saat bersamaan dunia perbankan dapat meningkatkan kepercayaan dari masyarakat. Eksistensi dari Lembaga Penjamin Simpanan yang utama adalah menciptakan kepercayaan masyarakat kepada institusi perbankan, namun tidak dapat dipungkiri bahwa masih banyak masyarakat yang belum mengerti tentang fungsi Lembaga Penjamin Simpanan Berdasar latar belakang tersebut Penulis memilih judul tersebut sebagai judul penelitian, untuk mengetahui peran pemerintah khususnya peran dan fungsi Lembaga Penjamin Simpanan dalam melaksanakan tugas dan tanggung jawabnya untuk menjamin, melindungi dan memberikan kepastian hukum kepada masyarakat sebagai nasabah bank dalam likuidasi bank dalam hukum perbankan.

\section{Rumusan Masalah}

1. Bagaimana fungsi Lembaga Penjamin Simpanan Dalam Hukum Perbankan?

2. Bagaimana Bentuk Hubungan Hukum antara Lembaga Penjamin Simpanan dengan Bank?

3. Bagaimana Peran dan Langkah yang Diambil Lembaga Penjamin Simpanan dalam Dunia Perbankan di Indonesia Dalam Hal Bank tidak Sanggup Bayar?

\section{Pembahasan \\ Fungsi Lembaga Penjamin Simpanan Dalam Hukum Perbankan.}

Lembaga Penjamin Simpanan selanjutnya adalah sebuah lembaga negara dengan status badan hukum yang independen, transparan dan akuntabel dalam menjalankan tugasnya serta bertanggung jawab langsung kepada Presiden (http://www.lps.go.id/v2/home.php). Kemudian sebagaimana diatur dalam Pasal 62 Undang-undang Nomor 24 Tahun 2004 tentang Lembaga Penjamin Simpanan selanjutnya disingkat UU Lembaga Penjamin Simpanan, tata kelola (governance) Lembaga Penjamin Simpanan adalah One board system, yaitu Dewan Komisioner sebagai pimpinan Lembaga Penjamin Simpanan yang bertanggung jawab untuk merumuskan dan memutuskan kebijakan, sekaligus melakukan pengawasan terhadap pelaksanaan tugas dan wewenang Lembaga Penjamin Simpanan ( ${ }^{1}$ http://www.lps.go.id/v2/home.php?li nk=bentuk). Dalam Pasal 65 UU Lembaga Penjamin Simpanan, Dewan Komisioner ditetapkan oleh Presiden dan memiliki kewenangan memutuskan hal-hal yang strategis.

Dalam melaksanakan tugasnya, sebagaimana diatur dalam Pasal 7 UU Lembaga Penjamin Simpanan, Dewan Komisioner wajib melakukan rapat berkala yang disebut sebagai Rapat Dewan Komisioner untuk membahas halhal sebagai berikut:

1. Menetapkan kebijakan penjaminan nasabah.

2. Menetapkan kebijakan Lembaga Penjamin Simpanan dalam mendukung stabilitas sistem perbankan.

3. Mengevaluasi pelaksanaan penjaminan simpanan nasabah 
dan pelaksanaan peran Lembaga

Penjamin Simpanan dalam mendukung stabilitas sistem perbankan.

4. Menerima dan mengevaluasi hal-hal yang dilaporkan kepada Kepala Eksekutif; dan/atau

5. hal-hal lain yang berhubungan dengan tugas Lembaga Penjamin Simpanan.

Lembaga Penjamin Simpanan adalah lembaga yang independen, transparan, dan akuntabel dalam melaksanakan tugas dan kewenangannya. Lembaga Penjamin Simpanan memiliki fungsi yang amat penting, yakni sebagaimana diatur dalam Pasal 4 UU Lembaga Penjamin Simpanan., yakni :

1. Menjamin simpanan nasabah penyimpan .

2. Turut aktif dalam memelihara stabilitas sistem perbankan sesuai dengan kewenangannya.

Dalam menjalankan fungsinya sebagai penjamin simpanan nasabah penyimpan, Lembaga Penjamin Simpanan bertugas menetapkan dan merumuskan kebijakan pelaksanaan penjaminan simpanan serta melaksanakan penjaminan simpanan. (Indraatmaja ;2001) dan ketika terjadi penutupan bank gagal, tugas penjamin simpanan ini diaplikasikan dengan melakukan pembayaran klaim penjaminan atas simpanan nasabah bank yang dicabut, dan menunjuk tim likuidasi untuk membereskan aset dan kewajiban bank tersebut (Rizal Ramadhani;2006).

Lembaga Penjamin Simpanan melakukan pembayaran klaim penjaminan kepada nasabah penyimpan dari bank yang dicabut izin usahanya sepanjang telah memenuhi persyaratan yang telah ditetapkan oleh UU Lembaga Penjamin
Simpanan. Kriteria simpanan layak bayar oleh Lembaga Penjamin Simpanan adalah (Juanda Mamuaja;2015):

1. Tercatat dalam pembukuan bank.

2. Tingkat bunga simpanan tidak melebihi tingkat bunga penjaminan.

3. Tidak melakukan tindakan yang merugikan bank.

Ketiga kriteria layak bayar tersebut di atas dikenal dengan 3T. Namun untuk tingkat bunga simpanan tidak melebihi tingkat bunga penjaminan tidak berlaku untuk bank syariah.

Pembayaran klaim penjaminan dapat dilakukan secara tunai atau pembayaran lain yang setara dan setiap pembayaran dilakukan dalam mata uang rupiah. Simpanan dalam mata uang asing dibayarkan berdasarkan kurs tengah bank Indonesia. Dalam hal nasabah penyimpan pada saat yang bersamaan mempunyai kewajiban kepada bank, maka pembayaran klaim penjaminan dilakukan setelah kewajiban nasabah penyimpan kepada bank terlebih dahulu diperhitungkan (Juanda Mamuaja;2015).

Pasal 19 UU Lembaga Penjamin Simpanan menentukan, klaim pembayaran dinyatakan tidak layak dibayar apabila berdasarkan hasil verifikasi :

1. Data simpanan nasabah dimaksud tidak tercatat pada bank.

2. Nasabah penyimpan pihak yang diuntungkan secara tidak wajar.

3. Nasabah penyimpan merupakan pihak yang menyebabkan keadaan bank menjadi tidak sehat.

Melalui aset recovery, pembayaran klaim penjaminan tersebut di kemudian hari diupayakan diperoleh kembali oleh Lembaga Penjamin Simpanan dengan cara melakukan 
pencairan aset dan/atau penagihan piutang kepada debitur sesuai urutan preferensi yang ditentukan UU Lembaga Penjamin Simpanan.

Terkait dengan fungsi sebagai Penjamin simpanan nasabah penyimpan, Pasal 8 UU Lembaga Penjamin Simpanan mengatur mengenai kepesertaan, premi, jenis simpanan yang dijamin dan nilai simpanan yangdijamin. Pengaturan dalam Undang-undang ini diejahwantahkan ke dalam Peraturan Lembaga Penjamin Simpanan guna pelaksanaan di lapangan. Fungsi ini dijalankan Lembaga Penjamin Simpanan tidak terlepas dengan lembaga-lembaga terkait, seperti dengan Bank Indonesia dalam hal penentuan besaran suku bunga penjaminan, dimana dalam menentukan besaran suku bunga penjaminan Lembaga Penjamin Simpanan harus memperhatikan besaran BI rate. Sedangkan dalam hal nilai yang dijamin Lembaga Penjamin Simpanan tidaklah memiliki kewenangan penuh untuk menentukan nilainya melainkan harus di bicarakan dengan Dewan Perwakilan Rakyat, dan kemudian ditetapkan dalam Peraturan Pemerintah (Juanda Mamuaja;2015;44).

Dalam rangka melaksanakan tugasnya sebagaimana dimaksud dalam Pasal 5 UU Lembaga Penjamin Simpanan, Lembaga Penjamin Simpanan mempunyai wewenang yaitu menetapkan dan memungut premi penjaminan serta menetapkan dan memungut kontribusi pada saat bank Pertama kali menjadi peserta.Setiap bank yang melakukan kegiatan usaha di wilayah Republik Indonesia wajib menjadi peserta penjaminan Lembaga Penjamin Simpanan. Perihal mengenai kontribusi kepesertaan bagi bank-bank yang menjadi peserta Lembaga Penjamin Simpanan ini diatur lebih lanjut di dalam Peraturan Lembaga Penjamin Simpanan yang menyebutkan bahwa

1. Setiap bank wajib membayar kontribusi kepesertaan pada saat bank yang bersangkutan menjadi peserta penjaminan.

2. Kontribusi kepesertaan sebagaimana dimaksud pada ayat (1) ditetapkan sebesar $0,1 \%$ (satu per seribu) dari modal disetor bank, bagi bank yangmendapatkan izin usaha pada atau setelah ditetapkannya peraturan ini.

3. Modal disetor untuk kantor cabang dari bank yang berkedudukan di luar negeri merupakan modal bank sebagaimana diatur dalam ketentuan mengenai kewajiban penyediaan modal minimum yang ditetapkan Lembaga Penjamin Simpanan

Setiap bank yang telah menjadi peserta Lembaga Penjamin Simpanan diwajibkan untuk membayar premi penjaminan kepada Lembaga Penjamin Simpanan. Besarnya premi penjaminan yang harus dibayar oleh bank peserta tersebut ditetapkan oleh Lembaga Penjamin Simpanan. Kewenangan yang dimiliki oleh Lembaga Penjamin Simpanan tidak terlepas dari fungsi yang melekat padanya, sebagai penjamin simpanan nasabah bank dan juga sebagai pemelihara stabilitas sistem perbankan. Lazimnya suatu lembaga penjamin simpanan yang dibentuk di negara-negara lain, Lembaga Penjamin Simpanan juga diharapkan dapat menjalankan fungsinya dengan baik dalam menjamin simpanan nasabah bank secara terbatas sehingga mendukung upaya stabilitas sektor perbankan. Pada saat bersamaan, Lembaga Penjamin Simpanan juga 
diharapkan dapat menangani permasalahan yang dialami oleh bank peserta program penjaminan. Fungsi ini dilengkapi kewenangan untuk menangani penutupan bank bermasalah hingga pelaksanaan likuidasinya, semangat dari kelaziman fungsi ini adalah karena sebagai lembaga yang menjamin simpanan nasabah, Lembaga Penjamin Simpanan memiliki exposure risiko terbesar apabila bank pesertanya ditutup (Juanda Mamuaja;2015).

Terkait dengan fungsi Lembaga Penjamin Simpanan menurut Pasal 4 UU Lembaga Penjamin Simpanan sebagai penjamin simpanan nasabah di bank, sebagai berikut (Neni Sri Imayanti;2010):

1. Menjamin simpanan nasabah penyimpan;

2. Turut aktif dalam memelihara stabilitas sistem perbankan sesuai dengan kewenanganya.

Tugas Lembaga Penjamin Simpanan menurut Pasal 5 UU Lembaga Penjamin Simpanan (Neni Sri Imayanti;193):

1. Merumuskan dan menetapkan kebijakan pelaksanaan penjaminan simpanan

2. Melaksanakan penjaminan.

3. Merumuskan dan menetapkan kebijakan dalam rangka turut aktif memelihara stabilitas system perbankan.

4. Merumuskan, menetapkan dan melaksanakan kebijakan penyelesaian Bank Gagal (bank resolution) yang tidak berdampak sistemik.

5. Melakasankan penanganan bank gagal yang berdampak sistemik.

Wewenang Lembaga Penjamin simpanan menurut Pasal 6 UU Lembaga Penjamin Simpanan:

1. Menetapkan dan memungut premi jaminan.
2. Menetapkan dan memungut kontribusi pada saat bank pertama kali menjadi peserta;

3. Melakukan pengelolaan kekayaan dan kewajiban Lembaga Penjamin Simpanan;

4. Mendapatkan data simpanan nasabah, data kesehatan bank, laporan keuangan bank, dan laporan basil pemeriksaan bank sepanjang tidak melanggar kerahasiaan bank;

5. Melakukan rekonsiliasi, verifikasi, dan/atau konfirmasi atas data;

6. Menetapkan syarat, tata cara, dan ketentuan pembayaran klaim;

7. Menunjuk, menguasakan, dan/atau, menugaskan pihak lain untuk bertindak bagi kepentingan dan/atau atas nama Lembaga Penjamin Simpanan guna melaksanakan sebagian tugas tertentu;

8. Melakukan penyuluhan kepada bank dan masyarakat tentang penjaminan simpanan;

9. Menjatuhkan sanksi administratif. Sebagai lembaga yang berfungsi untuk menjamin simpanan nasabah di bank, Lembaga Penjamin Simpanan harus memiliki akses yang luas terhadap segala infomasi yang berkaitan dengan nasabah dan kondisi kesehatan bank, yang akan digunakan untuk menghitung risiko atas program penjaminan yang dilakukan Lembaga Penjamin Simpanan.

Kewenangan lain yang dimiliki oleh Lembaga Penjamin Simpanan adalah kewenangannya dalam rangka untuk menjalankan fungsinya sebagai pemelihara stabilitas sistem perbankan khususnya dalam penanganan dan penyelesaian bank gagal sebagaimana diatur dalam Pasal 6 UU Lembaga Penjamin Simpanan, yaitu : 
1. mengambil alih dan menjalankan segala hak dan wewenang pemegang saham, termasuk hak dan wewenang RUPS;

2. menguasai dan mengelola aset dan kewajiban Bank Gagal yang diselamatkan:

3. meninjau ulang, membatalkan, mengakhiri, dan/atau mengubah setiap kontrak yang mengikat Bank Gagal yang diselamatkan dengan pihak ketiga yang merugikan bank; dan

4. menjual dan/atau mengalihkan aset bank tanpa persetujuan debitur dan/atau kewajiban bank tanpa persetujuan kreditur.

Dalam menjalankan kewenangannya ini, Lembaga Penjamin Simpanan tidak berdiri sendiri, melainkan bekerjasama dengan lembaga lain yakni Lembaga Pengawas Perbankan yang dalam hal ini adalah Bank Indonesia dan juga pemerintah yang diwakili oleh Menteri Keuangan, di mana kerjasama Lembaga Penjamin Simpanan dengan 2 pihak ini dilakukan dalam hal untuk merumuskan kebijakan penyelesaian bank gagal. Selain dalam hal perumusan kebijakan, kerjasama Lembaga Penjamin Simpanan dengan 2 pihak ini terjadi ketika pelaksanaanya, seperti misalnya dalam penentuan suatu bank dalam kondisi bank gagal, hal ini sepenuhnya menjadi kewenangan Bank Indonesia, sehingga Lembaga Penjamin Simpanan hanya tinggal menerima saja bank dalam kondisi demikian tanpa ada kewenangan untuk campur tangan, dan kemudian bank gagal tersebut diputuskan untuk diselamatkan atau tidak diselamatkan.

$\begin{array}{llr} & \text { Lembaga Penjamin } & \text { Simpanan } \\ \text { dapat berfungsi } & \text { untuk } & \text { mengatur } \\ \text { keamanan dan } & \text { kesehatan } & \text { bank } \\ \text { secara umum. } & \text { Di samping r itu }\end{array}$

Lembaga Penjamin Simpanan juga dapat berfungsi sebagai pengawas yang dilakukan dengan cara memantau neraca, praktik pemberian pinjaman dan strategi investasi dengan maksud untuk melihat tandatanda financial distress yang mengarah kepada kebangkrutan bank. Oleh sebab itulah keberadaan Lembaga Penjamin Simpanan sebagai bagian dari sistem perbankan menjadi penting guna mencegah kepanikan nasabah dengan jalan meyakinkan nasabah tentang keamanan simpanan sekalipun kondisi keuangan bank menurun.

Pentingnya peran Lembaga Penjamin Simpanan dalam sistem perbankan dapat didasarkan pada beberapa pertimbangan, yaitu:

1. Dalam pertumbuhan perekonomian suatu negara, peranan sektor finansial yang stabil sangat penting dan inti kestabilan sektor finansial adalah stabilitas sistem perbankan domestik. Peranan penting sektor perbankan itu dapat dilihat dalam aspek sistem pembayaran yang memungkinkan terjadinya transaksi perdagangan. Di samping itu, bank melakukan penghimpunan dana secara lebih efisien dan untuk seterusnya disalurkan kepada masyarakat. Sebaliknya, dana masyarakat yang disimpan di bank sangat menentukan ekstensi dan keuntungan suatu bank.

2. Untuk mencegah terjadinya erosi kepercayaan masyarakat terhadap bank yang dapat mengakibatkan terjadinya rush yang sudah tentu dapat membahayakan bank secara individual dan sistem perbankan secara keseluruhan.

3. Dalam era globalisasi dengan kemajuan teknologi informasi dan 
komputer telah mengakibatkan terjadinya global market dimana dana bebas bergerak dari satu negara ke negara lain. Kalau pemilik dana kurang percaya pada sistem perbankan nasional, maka ia dapat menanamkan dananya di luar negeri (capital flight) yang dapat mengakibatkan hilangnya atau berkurangnya kekuatan yang produktif dari suatu negara.

Menurut Rudjito Lembaga Penjamin Simpanan dirancang dan dibentuk sebagai bagian dari jaring pengaman sistem keuangan (financial safety net) di Indonesia yang mencakup 4 (empat) elemen yaitu(Rudjito;2008):

1. Pengaturan dan pengawasan terhadap institusi-institusi keuangan dan pasar;

2. Bertindak sebagai lender of the last resort.

3. Skim penjaminan simpanan; dan

4. Manajemen krisis.

Yang termasuk ke dalam sistem jaring pengaman sistem keuangan adalah Departemen Keuangan selaku pemegang kekuasaan finansial, Bank Indonesia selaku pengawas dan lender of the last resort, dan Lembaga Penjamin Simpanan selaku pemegang kewenangan mengenai penjaminan simpanan nasabah. Departemen Keuangan, Bank Indonesia, serta Lembaga Penjamin Simpanan bersamasama menentukan kerangka dan prosedur jaring pengaman sistem keuangan yang dapat menggambarkan secara jelas tugas-tugas dan kewenangan setiap institusi yang terkait sekaligus mekanisme koordinasi terhadap pencegahan dan penanganan krisis financial. Pembentukan Lembaga Penjamin Simpanan diharapkan dapat lebih menjamin dana simpanan masyarakat di bank-bank. Dengan adanya Lembaga Penjamin Simpanan yang berperan sebagai penjamin terhadap simpanan nasabah bank, maka apabila terdapat bank yang mengalami kesulitan usaha, kemudian dicabut izin usahanya dan dilikuidasi, kedudukan nasabah tetap terjamin. Dengan kata lain, Lembaga Penjamin Simpanan merupakan bentuk nyata dari adanya penjaminan dan perlindungan terhadap dana simpanan masyarakat. Dengan adanya Lembaga Penjamin Simpanan menunjukkan terdapat jaminan secara eksplisit bagi nasabah penyimpan apabila bank dilikuidasi.

\section{Bentuk Hubungan Hukum antara Lembaga Penjamin Simpanan dengan Bank.}

Lembaga Penjamin Simpanan adalah lembaga independen yang dibentukberdasarkan undang-undang nomor 24 Tahun 2004 tentang Lembaga Penjamin Simpana. Bentuk hubungan hukum antara Lembaga Penjamin Simpanan dengan Banktelah tertuang dalam Undang-undang, baik itu Undang-undang tentang perbankan maupun Undang-undang tentang Lembaga Penjamin Simpanan.

Disamping telah dinyatakan dalam ketentuan Undang-undang, sebagai penjamin dana nasabah penyimpan bank, hubungan antara Bank dengan Lembaga Penjamin Simpanan memiliki kesamaan dengan asuransi atau pertanggungan dalam KUHD dan penanggungan (borgtocht) yang dikenal dalam KUHPerdata. Pasal 246 KUHDagang menetapkan"asuransi

ataupertanggungan adalah suatu perjanjian, dengan mana seorang penanggung mengikatkan diri kepada 
seorang tertanggung, dengan menerima suatu premi, untuk memberikan penggantian kepadanya karena suatu kerugian, kerusakan atau kehilangan keuntungan yang diharapkan, yang mungkin akan dideritanya karena suatu peristiwa yang tak tertentu"

Sedangkan pengertian asuransi menurutPasal 1 angka 1 UU No. 2 Tahun 1992 tentang Usaha Perasuransian merumuskan"asuransi atau pertanggungan sebagai perjanjian antara dua pihak atau lebih, dengan mana pihak penanggung mengikatkan diri kepada tertanggung, dengan menerima premi asuransi, untuk memberikan penggantian kepada tertanggung karena kerugian, kerusakan atau kehilangan keuntungan yang diharapkan atau tanggung jawab hukum kepada pihak ketiga yang mungkin akan diderita tertanggung, yang timbul dari suatu peristiwa yang tidak pasti, atau untuk memberikan suatu pembayaran yang didasarkan atas meninggal atau hidupnya seseorang yang dipertanggungkan"

Dari rumusan tentang asuransi di atas dapat disimpulkan bahwa Lembaga Penjamin Simpanan mirip dengan asuransiatau pertanggungan yaitu sama-sama memungut premi yang dimana ketentuan tersebut tertera dalam pasal 9 huruf c UU Lembaga Penjamin Simpanan yang berbunyi "sebagai peserta penjaminan sebagaimana dimaksud dalam pasal 8, setiap Bank wajib : c. membayar premi penjamina".

Selain terdapat persamaan antara Lembaga Penjamin Simpanan dengan asuransi atau pertanggungan, juga sedikitnya terdapat empat perbedaan antara lain (Sah Tobing Saputra;2013):

1. kebangkrutan bank bukan suatu kejadian yang berdiri sendiri sedangkan yang dijamin dalam asuransi adalah suatu peristiwa tertentu.

2. asuransi umum ditujukan untuk melindungi risiko akibat tindakan pihaklain yang tidak dapat dikontrol oleh pihak tertanggung. Sedangkan kebangkrutan bank sering kali disebabkan perbuatan diri sendiri, yaitu kesalahan manajemen.

3. Tujuan utama Lembaga Penjamin Simpanan tidak saja menjamin simpanan nasabah penyimpan, akan tetapi juga menjamin kelangsungan usaha individual bank.

4. Lembaga Penjamin Simpanan didukung penuh oleh pemerintah. Sedangkan dukungan pemerintah pada perusahaan asuransi tidak lumrah dilakukan.

Sedangkan Penanggunganmenurut pasal 1820 KUHPerdata ialah suatu persetujuan dimana pihak ketiga, demi kepentingan kreditur mengikatkan diri untuk memenuhi perikatan debitur, bila debitur tidak memenuhi perikatannya. Dari uraian diatas, juga terdapat kesamaan antara Lembaga Penjamin Simpanan dengan penanggungan (borgtocht) yaitu

1. Pertama, Ditinjau dari sifatnya, jaminan penanggungan tergolong pada jaminan yang bersifat perorangan yaitu adanya orang pihak ketiga (badan hukum) yang menjamin memenuhi perutangan manakaladebitur wanprestasi. Sedangkan Lembaga Penjamin Simpanan juga badan hukum yang menjamin simpanan kreditur bila debitur tidak sanggup bayar.

2. Penanggungan atau penjaminan melibatkan keberadaan suatu utang yang terlebih dahulu ada. Hal 
ini berarti tanpa keberadaan utang yang ditanggung tersebut, maka penanggungan atau penjaminan tidak pernah ada.

3. Penanggungan atau penjaminan dibuat semata-mata untuk kepentingan kreditur, dan bukan untuk kepentingan debitur.

4. Penanggungan atau penjaminan hanya mewajibkan memenuhi kepada kreditur manakala debitur telah terbukti tidak memenuhi kewajiban atau prestasi atau kewajibannya.

Dan juga terdapat perbedaan antara dengan penanggungan yaitu :

1. Pertama, Dalam pasal 1823 KUHPerdata " orang dapat mengangkat diri sebagai penanggung tanpa diminta oleh orang yang mengikatkan diri untuk suatu utang, bahkan juga dapat tanpa setahu orang itu. Orang dapat pula menjadi penanggung, bukan hanya untuk debitur utama, melainkan juga untuk seorang penanggung debitur utama itu".Jadi yang menjadi penanggung bisa sembarang orang, sedangkan dalam Lembaga Penjamin Simpanan yang juga sebagai penanggung hanya badan hukum Lembaga Penjamin Simpanan yang dapat menjadi penanggung".

2. Penanggungan atau penjaminan hanya mewajibkan memenuhi kepada kreditur manakala debitur telah terbukti tidak memenuhi kewajiban atau prestasi atau kewajibannya.Dan juga terdapat perbedaan antara Lembaga Penjamin Simpanan dengan penanggungan yaitu "penanggung tidak wajib membayar kepada kreditur kecuali jika debitur lalai membayar utangnya; dalam hal itu pun barang kepunyaan debitur harus disita dan dijual terlebih dahulu untuk melunasi utangnya". Jadi penanggung baru bertanggung jawab untuk membayar hutang debitur jika harta benda debitur sudah dijual dan hasilnya tidak mencukupi untuk melunasi hutangnya. Sedangkan Lembaga Penjamin Simpanan dalam membayar ganti rugi tanpa menjual barang debitur karena sudah ada penjaminan maksimal 2 miliar, penjulan aset debitur hanya digunakan untuk mengganti penyertaan modal sementara Lembaga Penjamin Simpanan dalam penanganan debitur.

3. Ketiga,perjanjian penanggungan bersifat acessoir artinya perjanjianpenanggungan akan batal demi hukum jika perjanjian pokok juga batal demi hukum, sedangkan Lembaga Penjamin Simpanan dilandaskan UU selama pasal 8 ayat 1 UU Lembaga Penjamin Simpanan LPS tidak diubah.

\section{Peran dan Langkah yang Diambil Lembaga Penjamin Simpanan dalam Dunia Perbankan di Indonesia Dalam Hal Bank tidak Sanggup Bayar.} Penjaminan simpanan nasabah bank yang dilakukan Lembaga Penjamin Simpanan bersifat terbatas tetapi dapat mencakup sebanyakbanyaknya nasabah. Setiap bank yang menjalankan usahanya di Indonesia diwajibkan untuk menjadi peserta dan membayar premi penjaminan. Dalam hal bank tidak dapat melanjutkan usahanya dan harus dicabut izin usahanya, Lembaga Penjamin Simpanan akan membayar simpanan setiap nasabah bank tersebut sampai jumlah tertentu.

Lembaga Penjamin Simpanan melakukan tindakan penyelesaian 
atau penanganan bank yang mengalami kesulitan keuangan dalam kerangka mekanisme kerja yang terpadu, efisien dan efektif untuk menciptakan ketahanan sektor keuangan Indonesia atau disebut Indonesia Financial Safety Net (IFSN). Lembaga Penjamin Simpanan bersama dengan Menteri Keuangan, Bank Indonesia, dan Lembaga Pengawas Perbankan (LPP) menjadi anggota Komite Koordinasi.

Tindakan penyelesaian atau penanganan Bank-Gagal oleh Lembaga Penjamin Simpanan didahului berbagai tindakan lain oleh Bank Indonesia dan LPP sesuai peraturan perundangundangan. Bank Indonesia, melalui mekanisme sistem pembayaran, akan mendeteksi bank yang mengalami kesulitan keuangan. LPP juga dapat mendeteksi kesulitan tersebut dan berupaya mengatasi dengan menjalankan fungsi pengawasannya, antara lain berupa tindakan agar pemilik bank menambah modal atau menjual bank, atau agar bank melakukan merger atau konsolidasi dengan bank lain.

Apabila kondisi bank yang mengalami kesulitan keuangan tersebut semakin memburuk, antara lain ditandai dengan menurunnya tingkat solvabilitas bank, tindakan penyelesaian dan penanganan lain harus segera dilakukan. Dalam keadaan ini, penyelesaian dan penanganan Bank Gagal diserahkan kepada Lembaga Penjamin Simpanan yang akan bekerja setelah terlebih dahulu dipertimbangkan perkiraan dampak pencabutan izin usaha bank terhadap perekonomian nasional. Dalam hal pencabutan izin usaha bank diperkirakan memiliki dampak terhadap perekonomian nasional, tindakan penanganan yang dilakukan Lembaga
Penjamin Simpanan yang didasarkan pada Keputusan Komite Koordinasi.

$$
\text { Dalam menilai kondisi }
$$

kesehatan bank, Lembaga Penjamin Simpanan menggunakan sumber data/informasi yang berasal dari laporan bank peserta penjaminan dan sumber lain yang relevan. Laporan yang disampaikan bank tersebut meliputi laporan keuangan bulanan dan laporan keuangan tahunan yang telah diaudit. Selain itu, dasar penilaian dapat berupa data/informasi yang diperoleh dari Bank Indonesia; perusahaan pemeringkat; pasar modal; media massa; dan/atau sumber lain. Untuk menunjang pelaksanaan penilaian diperlukan sinkronisasi serta keseragaman bentuk dan susunan laporan; keakuratan data; serta dukungan sistem informasi yang memadai.

Kemudian bila terjadi bank gagal, masyarakat perlu mengetahui bahwa resolusi atau penanganan sebuah bank gagal bisa dimasukkan dalam dua kategori dasar, yaitu: penyelesaian bank gagal yang tidak berdampak sistemik dan penanganan bank gagal yang berdampak sistemik. Berikut uraiannya

\section{a. Penanganan Bank gagal yang tidak berdampak sistemik.}

Pasal 22 ayat (1) huruf a UU No. 24 Tahun 2004 tentang LPS ditegaskan bahwa penyelesaian Bank Gagal yang tidak berdampak sistemikdilakukan dengan melakukan penyelamatan atau tidakmelakukan penyelamatan terhadap Bank Gagal dimaksud. Selanjutnya menurut pasal 24 ayat (1) UU No. 24 Tahun 2004 tentang LPS bahwa LPS menetapkan untuk menyelamatkan Bank Gagal yang tidak berdampak sistemik jika dipenuhi persyaratan sebagai berikut (Diana Ria Winati Napitulu;2010): 
1)Perkiraan biaya penyelamatan secara signifikan lebih rendah dari perkiraan biaya tidak melakukan penyelamatan bank dimaksud;

2)Setelah diselamatkan, bank masih menunjukkan prospek usaha yang baik;

3)Ada pernyataan dari RUPS bank yang sekurang-kurangnya memuat kesediaan untuk :
a) Menyerahkan hak dan wewenang RUPS kepada LPS;
b) Menyerahkan kepengurusan bank kepada LPS; dan
c) Tidak menuntut LPS atau pihak yang ditunjuk LPS apabila proses penyelamatan tidak berhasil, sepanjang LPS atau pihak yang ditunjuk LPS melakukan tugasnya sesuai dengan peraturan perundang- undangan

4)Bank menyerahkan kepada LPS dokumen mengenai :
a) Penggunaan pendanaan
fasilitas Indonesia;
dari Bank
b) Dana keuangan Nasabah Debitur;
c) truktur permodalan dan susunan pemegang saham 3(tiga) tahun terakhir; dan
d) Informasi lainnya yang terkait dengan asset, dibutuhkan oleh LPS. kewajiban termasuk permodalan bank yang

Setelah RUPS menyerahkan hak dan wewenang, maka LPS dapat melakukan tindakan sebagai berikut (Diana Ria Winati Napitulu) :

- Menguasai, mengelola, dan melakukan tindakan kepemilikan atas aset milik atau yang menjadi hak-hak bank dan/atau kewajiban bank;

- Melakukan Penyertaan Modal Sementara (PMS);

- Menjual atau mengalihkan aset bank tanpa persetujuan nasabah debitur dan/atau kewajiban bank tanpa persetujuan nasabah kreditur (purchase and assumption).

- Mengalihkan manajemen bank kepada pihak lain;

- Melakukan merger atau konsolidasi dengan bank lain;

- Melakukan pengalihan kepemilikan bank; dan

- Meninjau ulang membatalkan, mengakhiri,dan/atau mengubah kontrak bank yang mengikat bank dengan pihak ketiga, yang menurut LPS merugikan bank.

Jika semua ketentuan diatas dipenuhi, maka Lembaga Penjamin Simpanan dengan segala Kewenangan yang dimilikinya akan berusaha keras untuk menyelamatkan bank tersebut. Namun sebaliknya jika tidak terpenuhi, maka Lembaga Penjamin Simpanan akan mengusulkan kepada LPP untuk mencabut izin usaha bank tersebut untuk selanjutnya dillikuidasi. Jadi jelas bahwa tindakan penyelamatan bank gagal dalam bentuk penyuntikan modal atau Penyertaan Modal Sementara (PMS) bukanlah satusatunya tindakan penyelamatan yang bisa dilakukan Lembaga Penjamin Simpanan. Bisa dipahami bahwa banyaknya tindakan penyelamatan yang diberikan UU Lembaga Penjamin Simpanan karena Lembaga Penjamin Simpanan merupakan upaya terakhir dalam rangka penyelamatan sebuah bank gagal. Namun demikian, Lembaga Penjamin Simpanan juga dapat tidak 
melanjutkan proses penyelamatan Bank Gagal, jika:

1. Ditemukan bukti baru bahwa biaya penyelamatan menjadi sekurangkurangnya : (a) 200\% dari perkiraan biaya penyelamatan pada saat keputusan penyelamatan; atau (b) lebih besar dari $60 \%$ perkiraan biaya tidak menyelamatkan pada saat keputusan penyelamatan;

2. Berdasarkan penilaian LPP, kondisi keuangan bank menurun sehingga diperlukan tambahan modal untuk memenuhi ketentuan kecukupan tingkat solvabilitas dan likuiditas. Terhadap bank gagal yang tidak dilanjutkan proses penyelamatannya oleh

Lembaga Penjamin Simpanan, maka akan diusulkan kepada LPP untuk mencabut izin usaha bank tersebut lalu dilanjutkan dengan melakukan likuidasi. Pada prinsipnya, seluruh biaya yang dikeluarkan Lembaga Penjamin Simpanan dalam rangkapenyelamatan bank gagal merupakan penyertaan modal sementara Lembaga Penjamin Simpanan pada Bank Gagal yang diselamatkan. Kedudukan Lembaga Penjamin Simpanan dalam penyertaan modal sementara itu adalah sebagai pemegang saham dengan hak preferen. Untuk mendapatkan tingkat pengembalian yang optimal atas PMSnya, Lembaga Penjamin Simpanan bisa memperpanjang waktu penjualan saham bank.

Ketentuan mengenai penjualan saham tersebut adalah sebagai berikut: Lembaga Penjamin Simpanan harus menjual saham seluruh bank secara terbuka dan transparan dalam jangka waktu paling lama 2 tahun, namun masih dapat diperpanjang sebanyakbanyaknya 2 kali dengan masing-masing perpanjangan selama 1 tahun. Namun, apabila dalam jangka waktu tersebut, tingkat pengembalian yang optimal tidak dapat diwujudkan, maka sesuai Pasal 30 ayat (5) UU No. 24 Tahun 2004, Lembaga Penjamin Simpanan harus menjual saham bank dalam jangka waktu 1 tahun berikutnya. Dalam hal ekuitas bank bernilai positif pada saat penyerahan kepada Lembaga Penjamin Simpanan, Lembaga Penjamin Simpanan dan pemegang saham lama membuat perjanjianyang mengatur penggunaan hasil penjualan saham bank setelah penyelamatan denganurutan prioritas sebagai berikut:

1. Pengembalian seluruh biaya penyelamatan yang telah dikeluarkan oleh Lembaga Penjamin Simpanan;

2. Pengembalian kepada pemegang saham lama sebesar ekuitas pada saat penyerahan bank kepada Lembaga Penjamin Simpanan;

3. Jika masih terdapat sisa, maka dibagi secara proporsional kepada Lembaga Penjamin Simpanan dan pemegang saham lama. Sebaliknya, jika ekuitas bank bernilai nol atau negatif pada saat penyerahan kepada Lembaga Penjamin Simpanan, pemegang saham lama tidak memiliki hak atas hasil penjualan saham bank setelah penyelamatan.

\section{b. Penanganan Bank Gagal yang Berdampak Sistemik.}

Mekanisme penanganan bank gagal yang berdampak sistemik sesuai dengan Pasal 22 ayat (1) huruf b UU No. 24 Tahun 2004 tentang Lembaga Penjamin Simpanan ditegaskan bahwa penanganan Bank Gagal yang berdampak sistemik dilakukan dengan 
melakukan penyelamatan yang mengikutsertakan pemegang saham lama atau tanpa mengikut sertakan pemegang saham lama.

Penanganan Bank Gagal yang berdampak sistemik dilakukan dengan mengikutsertakan pemegang saham lama (open bank assistance) hanya dapat dilakukan apabila:

1. Pemegang saham Bank Gagal telah menyetor modal sekurangkurangnya $20 \%$ dari perkiraan biaya penanganan;

2. Ada pernyataan dari RUPS bank sekurang-kurangnya memuat kesediaan untuk:

(a).Menyerahkan kepada Lembaga Penjamin Simpanan hak dan wewenang RUPS; (b) Menyerahkan kepada Lembaga Penjamin Simpanan kepengurusan bank dan, (c) Tidak menuntut Lembaga Penjamin Simpanan atau pihak lain yang ditunjuk Lembaga Penjamin Simpanan dalam hal proses penanganan tidak berhasil, sepanjang Lembaga Penjamin Simpanan atau pihak yang ditunjuk Lembaga Penjamin Simpanan melakukan tugasnya sesuai dengan peraturan perundangundangan;

3. Bank menyerahkan kepada Lembaga Penjamin Simpanan, dokumen mengenai:

(a)Penggunaan fasilitas pendanaan dari Bank Indonesia; (b) Data keuangan nasabah debitur; (c) Struktur permodalan dan susunan pemegang saham 3 tahun terakhir dan (d) Informasi lainnya yang terkait dengan aset, kewajiban, dan permodalan bank yang dibutuhkan Lembaga

Penjamin Simpanan

Lembaga Penjamin Simpanan bertanggung jawab atas kekurangan biaya penanganan Bank Gagal yang berdampak sistemik setelah pemegang saham lama melakukan penyetoran modal sekurang-kurangnya $20 \%$ dari perkiraan biaya penanganan. Untuk selanjutnya, biaya penanganan Bank Gagal yang dikeluarkan oleh Lembaga Penjamin Simpanan menjadi penyertaan modal sementara Lembaga Penjamin Simpanan pada bank tersebut.

Lembaga Penjamin Simpanan wajib menjual seluruh saham bank dalam penanganan secara terbuka dan transparan paling lama 3 tahun dan dapat diperpanjang sebanyakbanyaknya 2 kali dengan masing-masing perpanjangan selama 1 tahun untuk memperoleh tingkat pengembalian yang optimal. Namun, apabila dalam jangka waktu tersebut tingkat pengembalian yang optimal tidak dapat diwujudkan, Lembaga Penjamin Simpanan harus menjual saham bank dalam jangka waktu 1 tahun berikutnya. Dalam hal ekuitas bank bernilai positif setelah pemegang saham lama melakukan penyetoran modal, Lembaga Penjamin Simpanan dan pemegang saham membuat perjanjian yang mengatur penggunaan hasil penjualan saham bank dengan urutan sebagai berikut :

1. Pengembalian seluruh biaya penanganan yang telah dikeluarkan oleh Lembaga Penjamin Simpanan;

2. Pengembalian kepada pemegang saham lama sebesar ekuitas pada posisi sesaat setelah pemegang saham lama melakukan penyetoran modal;

3. Jika masih terdapat sisa, maka dibagi secara proporsional kepada 
Lembaga Penjamin Simpanan dan

pemegang saham lama.

Sebaliknya, jika ekuitas bank bernilai nol atau negatif setelah pemegang saham lama melakukan penyetoran modal, pemegang saham lama tidak memiliki hak atas hasil penjualan saham bank. (Pasal 35 UU No. 24 Tahun 2004).

Penanganan Bank Gagal tanpa mengikutsertakan pemegang saham lama akan ditempuh, apabila persyaratan untuk penanganan Bank Gagal dengan mengikutsertakan pemegang saham lama tidak dapat dipenuhi.

Tahap selanjutnya, terhitung sejak Lembaga Penjamin Simpanan menetapkan untuk melakukan penanganan Bank Gagal tanpa mengikutsertakan pemegang saham lama, Lembaga Penjamin Simpanan akan mengambil alih segala hak dan wewenang RUPS, kepemilikan dan/atau kepentingan lain pada bank dimaksud.

Seluruh biaya penanganan Bank Gagal yang dikeluarkan oleh Lembaga Penjamin Simpanan menjadi penyertaan modal sementara Lembaga Penjamin Simpanan pada bank. Penjualan seluruh saham bank dilakukan dalam jangka waktu paling lama 3 tahun dan dapat diperpanjang sebanyak-banyaknya 2 kali dengan masing.masing perpanjangan selama 1 tahun, dalam hal pengembalian optimal (sekurangkurangnya sama dengan penyertaan modal sementara Lembaga Penjamin Simpanan) tidak dapat diwujudkan selanjutnya, Lembaga Penjamin Simpanan harus menjual dalam satu tahun berikutnya dengan harga terbaik. Tentu saja, penjualan saham bank ini harus dilakukan secara terbuka dan transparan. Namun, apabila dalam jangka waktu tersebut, tingkat pengembalian yang optimal tidak dapat diwujudkan, maka sesuai Pasal 42 ayat
(5) UU No. 24 Tahun 2004, Lembaga Penjamin Simpanan harus menjual saham bank dalam jangka waktu 1 tahun berikutnya. Dalam hal ekuitas bank bernilai positif pada saat penyerahan kepada Lembaga Penjamin Simpanan, maka Lembaga Penjamin Simpanan dan pemegang saham lama membuat perjanjian yang mengatur penggunaan hasil penjualan saham bank setelah penanganan dengan urutan prioritas sebagai berikut:

1. Pengembalian seluruh biaya penyelamatan yang telah dikeluarkan oleh Lembaga Penjamin Simpanan;

2. Pengembalian kepada pemegang saham lama sebesar ekuitas pada saat penyerahan bank kepada Lembaga Penjamin Simpanan;

3. Jika masih terdapat sisa, maka dibagi secara proporsional kepada Lembaga Penjamin Simpanan dan pemegang saham lama.

\section{Kesimpulan}

Berdasarkan hasil peneltian dan pembahasan pada bab sebelumnya maka dapat ditarik kesimpulan sebagai berikut:

1. Fungsi Lembaga Penjamin Simpanan yaitu menjamin simpanan nasabah dan turut aktif memelihara stabilitas sistem perbankan.Penjaminan oleh Lembaga Penjamin Simpanan diterapkanpada bank umum dan Bank Perkreditan Rakyat (BPR), baik bank konvensional maupun bank syariah dan ketika terjadi penutupan bank gagal, melakukan pembayaran klaim penjaminan atas simpanan nasabah dari bank yang dicabut izin usahanya.

2. Hubungan hukum yang terbentuk antara Lembaga Penjamin Simpanan dengan Bank telah tertuang dalam 
Undang-Undang No. 7 Tahun 1992 tentang Perbankan sebagaimana telah diubah dengan UndangUndang No. 10 tahun 1998 yang diatur dalam Pasal 37B ayat (1) "setiap bank wajib menjamin dana masyarakat yang disimpan pada bank yang bersangkutan" dan ayat (2) "untuk menjamin simpanan masyarakat pada bank sebagaimana dimaksud dalam ayat (1) dibentuk Lembaga Penjamin Simpanan" sedangkan dalam Undang-Undang No. 24 tahun 2004 tentang Lembaga Penjamin Simpanan diatur pada pasal 8 ayat (1) "Setiap Bank yang melakukan kegiatan usaha di wilayah Negara Republik Indonesia wajib menjadi peserta Penjaminan". Hubungan hukum antara Lembaga Penjamin Simpanan dengan Bank dapat diasumsikan sebagai hubungan hukum antara penanggung dengan tertanggung. Sebagaimana diatur dalam pasal 246 KUHD dimana Bank sebagai tertanggung dan Lembaga Penjamin Simpanan sebagai penanggung, hal ini disebabkan adanya kewajiban Bank untuk membayar premi kepada Lembaga Penjamin Simpanan menurut pasal 9 huruf c Undang-Undang No. 24 Tahun 2004 tentang Lembaga Penjamin Simpanan. Letak perbedaanya bahwa asuransi menjamin evenemen ( peristiwa yang tidak tentu kapan terjadinya) sedangkan yang dijamin Lembaga Penjamin Simpanan jika bank tersebut tidak sanggup membayar uang nasabahnya. Lembaga Penjamin Simpanan juga dapat dikatakan sebagai borgtocht di KUHPerdata yakni merupakan badan hukum yang menjamin perutangan manakala debitur wanprestasi dan penjaminan tersebut semata-mata untuk kepentingan kreditur namun bedanya, Lembaga Penjamin Simpanan dalam membayar penjaminan tersebut dengan penyertaan modal sementara(PMS) yang nantinya akan diganti dengan penjualan saham Bank, sedangkan dalam borgtocht barang kepunyaan debitur harus dijual terlebih dahulu untuk membayar penjaminan.

3. Peran Lembaga Penjamin Simpanan dalam hal Bank tak sanggup bayar adalah melakukan penyelesaian atau penanganan terhadap Bank Gagal tersebut yang akan diuraikan sebagai berikut:

a. Penyelesaian Bank gagal yang tidak berdampak sistemik :

Lembaga Penjamin Simpanan melakukan penyelesaian Bank Gagal yang tidak berdampak sistemik setelah LPP atau Komite Koordinasi menyerahkan penyelesaiannya kepada Lembaga Penjamin Simpanan. Penyelesaian Bank Gagal yang tidak berdampak sistemik dilakukan dengan melakukan penyelamatan atau tidak melakukan penyelamtan terhadap Bank Gagal tersebut. Selanjutnya keputusan untuk melakukan penyelamatan atau tidak melakukan penyelamatan sekurang-kurangnya didasarkan pada perkiraan biaya terrendah antara melakukan penyelamatan dan tidak melakukan penyelamatan. Apabila dilakukan penyelamatan maka Lembaga Penjamin Simpanan akan:

1) Menguasai, mengelola, dan melakukan tindakan kepemilikan atas aset milik bank;

2) Melakukan Penyertaan Modal Sementara;

3) Menjual atau mengalihkan aset bank tanpa persetujuan nasabah debitur atau kreditur; 
4) Melakukan merger atau konsolidasi dengan bank lain dan meninjau ulang, membatalkan, mengakhiri, dan/atau mengubah kontrak bank yang mengikat bank dengan pihak ketiga, yang menurut Lembaga Penjamin Simpanan merugikan bank.

\begin{tabular}{lrr}
\multicolumn{1}{c}{ Jika } & tidak & dilakukan \\
penyelamatan & maka & Lembaga \\
Penjamin & Simpanan & akan \\
mengusulkan & kepada LPP & untuk \\
mencabut izin usaha bank tersebut & usa bank \\
untuk selanjutnya dilikuidasi. \\
b. Penanganan Bank Gagal yang \\
berdampak sistemik:
\end{tabular}

Penanganan Bank Gagal yang berdampak sistemik dilakukan dengan melakukan penyelamatan yang mengikutsertakan pemegang saham lama atau tanpa mengikutsertakan pemegang saham lama. Penanganan Bank gagal yang berdampak sistemik dapat dilakukan bila pemegang saham Bank gagal telah menyetor sekurangkurangnya $20 \%$ dari perkiraan biaya penanganan. Kemudian pemegang saham dan pengurus Bank melepaskan hak dan kepengurusan kepada Lembaga Penjamin Simpanan dan apabila Lembaga Penjamin Simpanan tidak berhasil melakukan penanganan maka pengurus Bank dan pemegang saham tidak dapat menuntut.

Lembaga Penjamin Simpanan Kemudian dalam hal ekuitas Bank bernilai positif maka dibuat perjanjian antara Lembaga Penjamin Simpanan dengan pemegang saham lama yang mengatur penggunaan hasil penjualan saham Bank yang meliputi pengmbalian seluruh biaya penanganan yang telah dikeluarkan Lembaga Penjamin Simpanan dan pengembalian kepada pemegang saham lama sebesar ekuitas pada posisi sesaat setelah pemegang saham lama melakukan penyetoran modal. Bila ekuitas Bank bernilai negatif maka pemegang saham lama tidak memiliki hak atas hasil penjualan saham Bank. Sedangkan penanganan Bank Gagal yang berdampak sistemik tanpa mengikutsertakan pemegang saham lama seperti penanganan pada Bank Gagal yang tidak berdampak sistemik. Seluruh biaya penanganan Bank Gagal yang dikeluarkan oleh Lembaga Penjamin Simpanan menjadi Penyertaan Modal Sementara (PMS) Lembaga Penjamin Simpanan pada Bank.

\section{Daftar Pustaka}

Abdullah, Thamrin Francis Tantri, Bank dan Lembaga Keuangan, Raja Grafindo Persada, Jakarta, 2008.

Batunanggar, S. Indonesia's Banking Crisis Resolution : Lesson and the Way Forward, Occasional Internal Paper, Desember 2002.

Fuady Munir, Hukum Perbankan Modern Kesatu, Bandung: Citra Aditya Bakti, 2003.

Haryono Sunaryati, Penelitian Hukum Di Indonesia Pada Akhir Abad ke 20, Alumni, Bandung, 1994.

Hermansyah, Hukum Perbankan Nasional Indonesia, Jakarta, Kencana Prenada,, 2010.

Indraatmaja Agung B.G.B , Lembaga Penjamin Simpanan:

Manfaatnya Bagi Nasabah dan Bank, Jakarta, Magister Hukum Universitas Indonesia, 2001.

Kusumaningtuti, Peranan Hukum Dalam Penyelesaian Krisis Perbankan Di Indonesia, Raja Grafindo Persada, Jakarta 2010.

Imayanti, Neni Sri Pengantar Hukum

Perbankan Indonesia, Bandung, PT Refika Aditama, 2010.

Mamuja, Juanda Lembaga Penjamin Simpanan Dalam Rangka Perlindungan Hukum Bagi Nasabah Perbankan DiIndonesia. 
Lex Privatum, Vol.III/No. 1/JanMar, 2015.

Napitulu Diana Ria Winati, Lembaga Penjamin Simpanan di Indonesia,Jakarta, PT Bumi Intitama Sejahtera, 2010.

Ramadhani, Rizal Likuidasi Terhadap Bank yang Berbentuk Hukum Perusahaan Daerah: Suatu Upaya Perlindungan Hukum terhadap Kepentingan Lembaga Penjamin Simpanan dalam Pelaksanaan Program Penjaminan Simpanan, Buletin Hukum Perbankan dan Kebanksentralan Vol. 4 Nomor 3 Desember 2006.

Rudjito, Opening Remark IADI 6thAsia Regional Committee Meeting \& International Conference.

(Makalah), Jakarta, 2008.

Pangestu Mari Elka, The Indonesia Bank Crisis dan Restructuring : Lesson and Implications for Other Developing Countries, G-24 Discussion Paper Series No. 23 United Nations Conference on Trade and Development, November 2003.

Saputra Sah Tobing, Tinjauan Yuridis Mengenai Peranan Lembaga Pejamin Simpanan , Fakultas Hukum , Universitas Muhammadiyah Surakarta, 2013.

Soekanto, Soerjono Pengantar Penelitian Hukum, Penerbit Universitas Indonesia, Jakarta, 1986.

dan Sri Mamudji, Peneliti Hukum Normatif: Suatu Tinjauan Singkat, Rajawali, Jakarta, 2006.

Rasjidi Lili dan Liza Sonia Rasjidi, Pengantar Metode Penelitian dan Penulisan Karya Ilmiah Hukum, Monograf, 2005.
Soemitro Roni Hanitijo, Metode Penelitian Hukum Dan Jurimetri, Ghalia Indonesia, Jakarta, 1994

\section{Peraturan Perundang-undangan}

Undang-undang Nomor 7 Tahun 1992 tentang Perbankan, yang telah diubah dengan Undang-undang Nomor 10 Tahun 1998 tentang Perubahan Undang- Undang Nomor 7 Tahun 1992 tentang Perbankan.

Undang-undang Nomor 24 tahun 2004 tentang Lembaga Jaminan Simpanan.

Undang-undang Nomor 21 Tahun 2011 tentang Otoritas Jasa Keuangan.

Peraturan Pemerintah Pengganti Undang-Undang Nomor 3 Tahun 2008 Tentang Lembaga Penjamin Simpanan

Peraturan Pemerintah Nomor 68 Tahun 1996 tentang Ketentuan Dan Tata Cara Pencabutan Izin Usaha, Pembubaran dan Likuidasi Bank.

Peraturan Pemerintah Nomor 25 Tahun 1999 tentang Ketentuan Dan Tata Cara Pencabutan Izin Usaha, Pembubaran dan Likuidasi Bank Umum.

Peraturan Pemerintah Nomor 66 Tahun 2008 tentang Besaran Nilai Simpanan Yang Dijamin Lembaga Penjamin Simpanan.

\section{Internet}

http://www.lps.go.id/v2/home.php diakses pada tanggal 11 April 2018

http://www.lps.go.id/v2/home.php?lin $\mathrm{k}=$ bentuk, diakses pada tanggal 11 April 2018 